\title{
A Selective Survey of the New Periodicals during the Year 1942
}

Miss Ulrich is chief of the periodicals division, New York Public Library.

$\mathrm{O}^{\mathrm{r}}$ THE NEW PERIODICALS appearing during the past year the majority are those directly concerned with the startling changes and growth of the war effort. Publications of technical societies, trade journals in special fields, and the many new house organs have become indispensable to research and to adult education. Technical and scientific publications -many of which are restricted at this time-are directed primarily toward the immediate projects of offense and defense. Trade journals serve an increased need through their record of manufacture and distribution of goods, the movements of raw materials, priorities, rationing, price fixing, and taxation. House organs, steadily gaining wider recognition, often give vital information illustrating production processes. Representative examples are those published by E. I. Du Pont de Nemours \& Co., American Telephone and Telegraph Co., General Motors Corporation.

Critical periodicals and those dealing specifically with subjects within the humanities have suffered under forced economies, and the lack of both means and men to develop any one field of interest has compelled many to cease publication. However, interest in universal changes is common to all readers, and those periodicals written in a more popular style and accompanied by colored and graphic illustrations reach a large and growing audience. The formerly desired "quality" group shows a noticeable decline of fiction and short stories.

Under international relations the new publications from South America, Mexico, and Cuba make available more and better material, while within our own borders human relationship is evidenced by worthy Negro publications and more and more space devoted to racial problems through articles appearing in established periodicals. Lastly, no comment on the year's publications would be complete without mention of four well-known foreign periodicals which have taken up their exiled issuance in this country, namely: Byzantion, Erkenntnis (journal of unified science), Beaux Arts, and Isis. In attempting to review the most valuable additions of the year several librarians working with collections of specific subjects have been asked to contribute their findings.

\section{Technological Periodicals}

Laura A. Eales, head of the technology department of the Bridgeport Public Library, whose experience in that vast war production center gives authority, contributes the following: 
Electronic Industries which appeared this November is a monthly edited by $\mathrm{Dr}$. Orestes H. Caldwell, the former Federal Radio Commissioner. Similar in scope to Electronics, this publication gives news interpretations and engineering features useful to engineers, production executives, and to those industries in which electronics equipment is used. Included are new patents, abstracts from the world's press, book reviews, and the bulletins, catalogs, and leaflets of the trade literature. There are good illustrations and also many graphs and diagrams demonstrating the structure and details of various equipment.

Out of the acceleration given to aviation by war conditions three periodicals have come which are worthy of mention. Air Tech; The Magazine of Aircraft, Maintenance, and Operation, v. I, no. I, October 1942, published in the interests of the U.S. Army Air Forces Technical Training Command, is self-explanatory in its subtitle. The feature articles on aeronautical problems applicable to military planes operating all over the world are timely, and the fullpage illustrations of planes which are used for combat, transport, and experiment are outstanding. Excellent charts and diagrams are to be found in each issue. Air Transportation which brought out its first number last October is devoted exclusively to the subject of shipping-by-air and includes the interests of the shippers, manufacturers, forwarders, importers, and exporters. There are short news and review articles looking toward postwar times when cargo-by-air will involve national and international policies of political, economic, and military moment. Wings, published by McGraw-Hill under contract with the U.S. Bureau of Aeronautics and U.S. Navy and Army Air Forces, is designed to be of practical help to the supervisory staff of the manufacturers of aircraft and aircraft accessories and is not sent to anyone outside of that field. Economies and short cuts of production are discussed and each method is fully reproduced with clear illustrations, diagrams, charts, and graphs. The Daily Chemical Market gives the record and prices of the chemical, drug, oil, paint, and plastic in- dustries and serves not only the industries in the war effort but also all those through whose hands these commodities pass, including the manufacturer and consumer. The immediate importance of new uses of chemicals and synthetic replacement of scarce materials gives value to this journal. New patents and trademarks are listed. Promising in value is Resins-RubbersPlastics, which is a loose-leaf monthly abstract service edited by H. Mark and Dr. E. S. Proskauer. The abstracts, averaging sixty-four pages, offer up-to-date reference literature comprising the chemistry, physics, and technology of resins, rubbers, and plastics, including cellulose and starch. In the latest issues are abstracts from German periodicals. Curves, graphs, and diagrams increase the value of this great service which is rendered unwieldy by the lack of a muchneeded index. The Plastics Digest, a monthly publication, v. I, no. I, January 1942, also abstracts articles and books and covers much the same field as the above but in briefer form. The Archives of Biochemistry, a very informative bimonthly journal which is a definitely technical and scholarly treatise, appeared in October 1942, dealing with the subjects of proteins, metabolism, nutrition, hormones, vitamins, viruses, photosynthesis, plane chemistry, experimental chemotherapy, organic chemistry as related to living organisms, and colloid science in its biological applications. Nutrition Reviews, published by the Nutrition Foundation, Inc., in November 1942, and edited by Frederick J. Stare, Ph.D., M.D., assistant professor of nutrition, schools of medicine and public health, Harvard University, is a monthly abstracting service. Its purpose as stated in the Foreword is "to provide an authoritative, unbiased, editorially interpreted review of the world's current research progress in the science of nutrition."

\section{Natural Science Periodicals}

Amy L. Hepburn, librarian of the Natural Science Libraries of Columbia University, reviewing the periodical publications in that group, is quoted. 
Four contributions in the periodical field have been made to natural sciences in 1942 . Chief among these is the quarterly entitled Federation Proceedings, published by the Federation of American Societies for Experimental Biology, which offers the experimental biologist a series of abstracts of papers to be presented at the scientific sessions of the Federation of American Societies for Experimental Biology, composed of the American Physiological Society, the American Society of Pharmacology and Experimental Therapeutics, the American Society for Experimental Pathology, and the American Institute of Nutrition. This quarterly of some six hundred pages has proved a useful contribution in the fields of physiology, biochemistry, pharmacology, pathology, and nutrition. Not only does it contain comprehensive abstracts of papers to be presented but in later issues appear "matter pertinent to federation membership and symposiums and other special papers presented at federation meetings as selected by the editorial board." The issues are most carefully indexed, both authors and subjects included, while in the abstract number the papers are grouped under the various societies which contribute. Diagrams and tables illustrate the longer papers. Next I should consider as claiming second place the Revue canadienne de biologie. In the establishment of this bimonthly periodical the objective is to bring French and English scientists into closer collaboration. Scanning the names of the Comite de Collaboration Scientifique, made up of about fifty famous biologists, we realize the impressive background of this publication. England, France-in-exile, Canada, and several countries in South America are represented. Sponsored by the University of Montreal and emanating from that city where neither nationality predominates, this brave project to give both peoples an equal chance to contribute to research in experimental biology seems most commendable. Articles appear in either French or English. After each are a résumé and summary which present the gist in both languages. There are comprehensive bibliographies at the end of the articles. Some of the contributions are profusely illustrated with plates and diagrams and although the former do not reach the high standard of prewar German publications, they are remarkably good for a review which cannot spend the large sums demanded for the best reproductions. Thirdly, the Journal of Animal Science, a quarterly, published by the American Society of Animal Production, is represented by an editorial board of outstanding scientists, many of whose names appear in American Men of Science. Contributions in the fields of animal genetics, nutrition, and physiology, particularly as they apply to livestock production, appear in its issues. The special subjects of growth and development are also included. Scattered over our country are the great agricultural experiment stations where vital research is carried on. This journal embodies investigation by scientists connected with these institutions as well as contributions from members of the staffs of the foremost colleges and universities. Abstracts of the papers to be presented at the annual meetings of the society are included. The news and notes sections list meetings of interest to the readers and personal items. Lastly, Boletin del instituto botanico de la universidad central de Ecuador. This botanical journal from South America is described by one librarian as "a good little publication worthy of encouragement." The subject matter consists of articles on systematic, pathological, and cytological botany. As is customary with the rank and file of South American publications the paper and printing leave much to be desired. This is particularly to be deplored in the case of the illustrations which appear cheap and second class. Following the main body of the number, "Notas" of scientific interest appear and "Sección Bibliográfica."

\section{Social Science Periodicals}

Rollin A. Sawyer, chief of the economics division of the New York Public Library, writes:

Among the new periodicals in the social sciences only one can be called outstanding, 
Agenda, a Quarterly Journal of Reconstruction, published by Humphrey Milford for the London School of Economics and Political Science. The editor is Professor G. N. Clark and the advisory committee consists of the governors and officers of the school. V. I, no. I, is dated January 1942 . It is handsomely printed on excellent paper, though the type is rather small. The introductory statement says "it will cover the whole field of reconstruction, domestic and international, political, economic, and social." The first to deal with subjects already so controversial and certain to be bitterly disputed after the war, this journal is indispensable. The Journal of Legal and Political Sociology, v. I, no. I-2, was published in October 1942. It is to be issued semiannually by the Philosophical Library, Inc., New York. The editor is Georges Gurvich of Columbia University and the editorial board includes Karl N. Llewellyn and R. M. Maclver of Columbia, Bronislaw Malinowski of Yale, Roscoe Pound of Harvard, R. H. Lowie of the University of California, and T. V. Smith of the University of Chicago. The Journal "does not propose to cover dogmatic techniques or the philosophy of law, but rather the problems of legal and political behavior and legal institutions and symbols in their functional relationship with types of groups and inclusive societies." The excellence of its editorial board is scarcely equalled by its typography.

Libraries interested in Latin America may find the following useful. Revista del banco de la republica oriental del Uruguay, Montevideo, v. I, no. I, April 1942, is a monthly with the usual characteristics of such journals, economic review of the month, and index numbers relating to various aspects of the national economy. Orientacāo econômica $e$ financeira is an illustrated monthly printed on fairly good paper, published in Porto Alegre, Brazil. V. I, no. I, is dated April 1942. It is devoted to the industries, foreign trade, and general economic situation of the state of Rio Grande do Sul. Revista de economia, finanzes administración, Montevideo, v. I, no. I, January 1942 , is the organ of the Asociacion
Nacional de Contadores y Peritos Mercantiles del Uruguay, but it contains articles of general interest as well as a professional section. The paper used is only fair. Revista nacional de ciencias politico-economico-sociales, Havana, v. I, no. I, December I94I. On the cover is printed "El Nuevo evangelico de la reforma cubana." It appears to have a definite economic program including the creation of a national bank, industrialization of agriculture, fishing, and mining, and nationalization of wealth; in short, a collective economy. Each issue contains many but brief articles. It is printed on good paper. The editor is J. M. Alvarez Acevedo. Politica economica; revista mensual al servicio de los intereses de América, Buenos Aires, v. I, no. I, November I94I. The editorial board includes representatives of Argentina, Bolivia, Chile, Paraguay, Panama, and Uruguay. Inter-American commerce is the field of this periodical, especially the relations of the countries in the basin of the Rio de la Plata with the U.S.A. Printed on poor paper.

\section{Art Periodicals}

Pauline V. Fullerton, chief of the art division of the New York Public Library, discusses two new art magazines, both of which are published in other countries.

Ars: revista mensual, v. I, no. I, January 1942, Mexico City. The pages of this new periodical are open to contributors from all the countries of North, Central, and South America. Its subject matter is characterized by a wide inclusion in the fields of art, poetry, music, theatre, and cinema. Useful features are notes on contributors and record of new books published in the Americas. Museu: revista de arte, arqueologia, tradiçōes, v. I, no. I, June 1942, published in Pôrto, Portugal. The first issue of this quarterly gives promise of making important contributions to the bibliography of Portuguese art, in both its historical and contemporary aspects. It includes reviews of new Portuguese titles and begins a checklist of Portuguese artists with sources for information about each individual. 
Finally, the editor adds the following: The California Folklore Quarterly published by the California Folklore Society appeared in January 1942. It constitutes a real contribution to the cultural history of the Pacific Coast area and is a worthy companion to similar journals published in the United States and abroad. Competent contributions made this year to historical knowledge and published by their respective historical societies are the $A r$ kansas Historical Quarterly, Tennessee Historical Quarterly, and Rhode Island History. The new magazine $V V V$ (Triple $V$ ) is founded by Andre Breton. Its editor is the young American sculptor, David Hare. The associate editor is Max Ernst, the German surrealist painter who now lives in New York. The aim of the magazine is to unite the creative forces of the arts, especially of painting, literature, and poetry during the crisis of war. Since Andre Breton is the founder of the magazine, it has strong surrealist tendencies. Its articles and illustrations deal chiefly with the aspects of the dream world and its interrelation to daily activities. Polish Science and Learning, v. I, no. I, June 1942 , is an irregular publication started by the association of Polish scientific leaders in Great Britain. The purpose is "to collect and preserve what they can of their thousand-year-old cultural heritage." The first issue, which is excellent including the format, creates the hope that the standard will be maintained in future issues. The Negro Quarterly, embodying Negro thought and opinion, began with the spring issue of 1942 and is published by the Negro Publication Society of America. "Its purpose is to aid in furthering the literary, social, and cultural advancement of the Negro people."
The quarterly is a good representation, well edited and practicable, while the Racial Digest, v. I, no. I, January 1942, condenses articles on the Negro from a wide field of interests. Waterways (River waterways), v. I, no. I, March 1942, gives the "coordination of railways and highways to the end that they may adequately serve the growing needs of American commerce and industry" and is graphically expressed by means of surveys and diagrams. Revista argentina de historia de la medicina, the official organ of the Ateneo de Historia de la Medicina, v. I, no. I, January 1942, publishes scholarly articles on the history of medicine. Following the main body of the journal, "Notas y Commentarios," courses given in the history of medicine in various universities are discussed. The format is attractive. La Cultura en México; boletin de la comision mexicana de cooperacion intelectual, v. I, no. I, January 1942, interprets the intellectual and artistic life of Mexico today. While less pretentious and printed on poorer paper, the content compares favorably with Cuadernos americanos, published in 1941, and Revista de literatura mexicana, in 1940.

\section{Periodicals}

Agenda. London Sihool of Economics and Political Science, London. I gn.

Air Tech. Philip-Andrews Publishing Co., 545 Fifth Ave., New York City. \$2.50.

Air Transportation. John F. Budd, Io Bridge St., New York City. \$5.

Archives of Biochemistry. Academic Press, 125 E. 23rd St., New York City. \$5.50 per volume.

Arkansas Historical Quarterly. Arkansas Historical Association, Fayetteville. Membership. Ars: revista mensual. Av. Juarez 6o, Mexico, D.F. $\$ 22$. (Mex.)

Bolctin del instituto botanico. Universidad Central del Ecuador, Quito. Price not given (exchange encouraged).

California Folklore Quarterly. University of California Press, Berkeley. \$1.25 per number.

Cultura en Mexico. Edificio de la Secretaria de Education Publica, Mexico, D.F. Price not given

Daily Chemical Market. Atlas Publishing Co., 133 W. 21 st St., New York City. \$15.

Electronic Industries. M. Clements, 480 Lexington Ave., New York City. \$3. 
Federation Proceedings. Federation of American Societies for Experimental Biology, ig W. Chase St., Baltimore. $\$ 4$.

Journal of Animal Science. Kansas State College, Manhattan. \$3.

Journal of Legal and Political Sociology. Philosophical Library, Inc., I 5 E. 40th St., New York City. \$3.50

Museu. Círculo Dr. Jose de Figueiredo, Palacio de Carrancas, Rue de D. Manuel II, Porto, Portugal. Price not given.

Negro Quarterly. Negro Publication Society of America, Inc., I W. I 25 th St., New York City. $\$ 2$.

Nutrition Reviews. The Nutrition Foundation, Inc., Chrysler Building, New York City. $\$ 2$.

Orientacao economica e financeira. Caixa I 044 , Rio Grande do Sul, Porto Alegre, Brazil. Price not given.

Plastics Digest. 523, New Brunswick, N.J. \$20.

Brition University Professors, Oxford University Press, London. 2s. $6 \mathrm{~d}$. per number.

Politica economica. Reconquista 28r, Buenos Aires, Argentina \$12.

Racial Digest. Community Publishing Co., 446 E. Warren Ave., Detroit. \$I.
Resins, Rubbers, Plastics. Interscience Publishe:s, Inc., 215 Fourth Ave., New York City. \$35.

Revista argentina de historia de la medicina. Ateneo de Historia de la Medicina, Esheverria 1606, Buenos Aires, Argentina. $\$ 6$.

Revista de economia, finanzes $y$ administracion. Asociacion Nacional de Contadores y Peritos Mercantiles del Uruguay, Avda. Agraciada 1464, Montevideo, Uruguay. Price not given.

Revista del banco de la republica oriental del Uruguay. Departamento de Investigaciones Ecoguay. Departamento de Investigaciones Eco-

Revista nacional de ciencias politico-economicosociales. Prado 358 , Havana, Cuba. \$5

Revue canadienne de biologie. University of Montreal, Canada. $\$ 6$.

Rhode Island History. Rhode Island Historical Society, Providence. Price not given.

Tennessee Historical Quarterly. Tennessee Histori$\mathrm{cal}$ Commission and the Tennessee Historical

Society, Nashville. \$2. New York City. \$4.

Waterways. Edited by John W. Black, Du Bois, $\mathrm{Pa}$. \$4.

Wings. McGraw-Hill Publishing Co., Inc., $330 \mathrm{~W}$. 42 nd St., New York City. (Not for general distribution.)

\section{Announcement Concerning Dr. Branscomb}

A ReCENTLy PUBLISHED RePort of the President, Duke University, Durham, North Carolina, carries the following announcement :

At the beginning of the year $1941-42 \mathrm{Dr}$. Harvie Branscomb resigned as director of libraries, to devote himself to his teaching in the Divinity School. His resignation, however, has not terminated his interest in library work. When Dr. Branscomb accepted the position of director in 1934 the library consisted of some 386,000 volumes and was beginning to assume the character of a university library. At the time of his resignation the number of volumes had increased to 632,000 and the library had taken its place among the fifteen major university libraries of the country. During Dr. Branscomb's administration many difficult problems had to be faced, and his aid and advice were invaluable to the Library Council in the formulation of new policies. Besides this, he organized the Friends of the Library, which now has a membership of over five hundred, and was chiefly responsible for the development of a program of library cooperation with the University of North Carolina, which has been of great significance to both institutions and has attracted widespread notice among librarians and university administrators. 